Please do not remove this page

RMIT

UNIVERSITY

\title{
The evolution of futures in school education
}

Gidley, Jennifer; Hampson, Gary

https://researchrepository.rmit.edu.au/esploro/outputs/9921861861201341/filesAndLinks?institution=61RMIT_INST\&index=null

Gidley, J., \& Hampson, G. (2005). The evolution of futures in school education. Futures: The Journal of Policy, Planning and Futures Studies, 37(4), 255-271. https://doi.org/10.1016/j.futures.2004.07.005

Published Version: https://doi.org/10.1016/j.futures.2004.07.005

Repository homepage: https://researchrepository.rmit.edu.au

(C) 2004 Elsevier Ltd

Downloaded On 2023/04/26 23:50:43 +1000

Please do not remove this page 


\title{
The Evolution of Futures in School Education
}

\author{
Published: Futures, (2005), Vol 37, No 4, pp. 255-271
}

\author{
Jennifer M Gidley and Gary P Hampson \\ Southern Cross University, Lismore, NSW, Australia \\ The Australian Foresight Institute, Swinburne University, Hawthorn, Melbourne, Australia 3122
}

\begin{abstract}
School education seems to be mostly stuck in an outdated industrial era worldview, unable to sufficiently address the significance and increasing rapidity of changes to humanity that are upon us. An integrated forward-looking view should, now more than ever, be of central importance in how we educate. Yet there is little sign that - unlike corporations - school systems are recognising the true value of futures studies. A brief history of futures in school education shows the significant role played by the World Futures Studies Federation in its evolution to date. The article also introduces integral analysis as a way of opening up new possibilities to help school education develop due foresight and to more fully realise its potential as a prime facilitator in individual and cultural evolution.
\end{abstract}

Keywords: Futures, School education, Integral, Steiner, Wilber

The task for the teacher at this moment is the same as it has always been, only now it seems more urgent, more important... Delving into the world of traffic jams and oxygen masks, space stations and tent cities, the teacher might offer us some signposts, or create wondrous lessons that inspire us and teach us about ourselves...I propose nothing new, only that teachers should expose the myths of progress and prosperity that are holding up the house of cards. They must bring into focus a vision which does not gloss over the facts behind the nightmare but which manages to engender enthusiasm about the potential of the human spirit despite the bleak circumstances. At the moment the young, especially, have no faith in the future, and so are unwilling to deal with the present except to try and make it as bearable as possible... We need teachers to remind us of our potential ... to participate in the great struggle of hope, renewal and a shared home. [1]

The formation of the World Futures Studies Federation (WFSF) - including the work of many of its members and the support it provides to them - has been crucial in enabling the development of futures in school education. The following brief review of futures in school education points to five traditions of futures studies, the last two of which are still emerging. The past and future state of play in futures in school education is analysed using a core component of Ken Wilber's integral framework. From this broad perspective it becomes evident that there are still many gaps. Based on this analysis, some indications for further research are suggested. These may form the basis of a working agenda for the WFSF Futures in Education working group currently chaired by David Hicks.

\section{A new perspective on the traditions of futures studies}

It is well recognised that at least three traditions of futures studies have developed since the 1960s. [2-6] In outline,

- the empirical tradition originated in the USA. It was supported by the formation of the World Future Society in the 1960s. Much of the early futures in education work falls into this category;

- the critical tradition originated in Europe and grew out of a critique of the overly empirical approach of futurists in the USA. This led to the foundation of the World Futures Studies Federation in the early 1970 s, which continues to this day to support a critical approach to futures. 
Much of the futures in school education work which has been driven by Richard Slaughter and David Hicks over the past two decades has its grounding in this approach; [7-13]

- the cultural tradition arose in large measure from the work of those WFSF members who sought to include non-Western cultures and to invoke a deeper consideration of civilizational futures. Sohail Inayatullah and Zia Sardar have been driving forces in this direction. [14-17] Although this perspective is gaining recognition generally, it has not yet significantly penetrated futures in school education.

There has been some debate as to whether any further iterations exist. However, an additional, 'proactive, activist' approach was proposed by Paul Wildman in the mid-nineties, which he called 'futuring'. [18] This has recently gained some support from Inayatullah who now refers to a fourth 'action research based' approach. [19] From a different quarter, Slaughter is also proposing a fourth approach, which he terms 'integral'. [20] Based on our analysis of the futures in school education field, the present authors attempt to resolve this discrepancy by proposing that there are actually two new perspectives that futurists need to take on board:

- the empowerment-oriented, action research component which has been lying dormant since the nineties and only just beginning to be acknowledged, [18, 21-25] and

- the integral futures model, which is newly emerging. [20, 26, 27]

In this framework, the empowerment/action research futures would be the fourth iteration and integral futures would be the fifth. It is vital that the futures studies field keeps abreast of rapid new developments in all fields of knowledge when constructing its own frameworks.

\section{A brief history of 'futures in school education'}

A summary of the development of futures in education can be found in Richard Slaughter's recent chapter, 'From Rhetoric to Reality'. [28] The US led the way: the first futures course in schools was in 1966. Further pilot projects led to the establishment of a number of centres. A second wave of interest continued with work by Kristen Druker in high schools and Ted Dixen in primary schools.

One of the major futures-oriented projects has been Paul Torrence's Future Problem Solving Program, still operating today. By 1995 approximately 200,000 students in all fifty US states were using the program's material. [28] It has also extended to other countries. A critique would be that the project strongly extols a 'technofuture'.

Another successful venture has been the 'Creating Preferred Futures Project'. This developed from Cole Jackson's major K-12 school project in Florida. It is an interdisciplinary, Web-based concept that links students worldwide in an interactive futures education forum. It is the only program of its kind specifically geared to school-aged students. [29]

In 1985, the Education and Futures Studies Conference in Barcelona in Spain - initiated by Jordi Serra - began the expansion of futures in education beyond the USA into Europe.

In the UK, David Hicks' work in curriculum innovation has been prolific. Much of his written work is directly aimed at teachers for classroom use. [8, 30-35] Latterly, his work, along with that of Cathie Holden, has led to futures being taken into the new national curriculum area of citizenship education. [34, 36]

Citizenship education is associated with the growing 'education for sustainability' movement that has come as a response to the 1992 Earth Summit. This movement has helped join together environmental educational innovators such as David Orr, Stephen Sterling and John Fien [37-39] with educational futurists such as David Hicks and Frank Hutchinson. [30, 40] In a collaborative achievement under the auspices of UNESCO, John Fien produced a CD-ROM for teachers. With 25 modules including 'a futures perspective in the curriculum', Teaching and Learning for a Sustainable Future deserves to be more widely known and used. [41] 
In Australia and New Zealand, several futures-based curriculum innovations have been introduced but most have faltered through lack of systemic support for teachers. In particular, Kathleen Rundell and Richard Slaughter developed an innovative four-semester program in futures for years eleven and twelve in Queensland. [28] Although evaluations confirmed this to be a highly effective model, it has only been used in a limited way and was dropped after its pilot phase. However, in both South Australia and Tasmania, futures is now one of the 'essential learnings' of the state syllabus. There are also sustainable futures projects in Western Australia. [42]

The activities of key WFSF members (particularly Tony Stevenson, former WFSF President, and Cesar Villanueva, former WFSF Secretary) were also instrumental in introducing futures in education into South East Asia with Conferences in the Philippines in 1996 and Malaysia in 1995 and '96. These conferences provided vital conceptual and moral support for educational practitioners and futures researchers from a variety of countries.

A general critique of current usage of the terms 'future' and 'futures' in educational discourse is that whilst they are increasingly common, much of this may be a superficial appropriation. [42] In a critical examination of ways in which futures were conceptualised by Australian educators, Noel Gough elucidated three main ways that futures had entered educational discourse:

- tacit futures - whereby 'the temporal categories of past and present receive far more frequent and explicit attention' than 'future' or 'futures' -- even in documents purporting to be about 'Future Directions in ...Education';

- token futures - referring to 'the invocation of futures concepts and terminology for purposes which are chiefly rhetorical or where they are part of a rationalisation of choices, decisions or judgements which may, in fact, have been made on other grounds';

- taken-for-granted futures - in particular, those future visions dominated by scientific and technological development. [43]

Much of the pre-1990 'futures in education' research included an exploration of young people's views of the future. Details from this research are given below.

\section{Young people's views about the future}

Western research from the 1980s and 90s indicated that young people felt deepening despair and powerlessness about the future, [30, 32, 44-49] especially regarding the environment, the economy, unemployment and health issues, notably drug abuse and AIDS. [40, 47, 50] (Research in other parts of the world mirrored these findings but also indicated a more complex story -- see below). [51]

These concerns were in regard to scenarios of a 'probable' future. But as Gough pointed out, "The children... may be telling themselves and the researchers stories about...futures they want to avoid." [52] To uncover deeper, underlying attitudes, and to place this negativity in perspective, Frank Hutchinson's research, drawing on Elise Boulding (1988), also investigated 'preferred' and 'proactive' futures. Three differing images were then pictured:

- feared futures: a world that is uncompassionate, physically violent, divided, mechanized, environmentally unsustainable and politically corrupt and deceitful;

- preferred futures: technocratic dreaming (especially from boys); the greening of science and technology (more common among girls); imagining intergenerational equity and making peace with people and planet;

- proactive futures: linking images of the world with action planning. [53]

Hutchinson also found that images of feared futures were more fluid and extensive than those of preferred futures. 
Richard Eckersley's research shows a large discrepancy between what youth expect and would wish to happen. Most do not expect life in Australia to be better in 2010. [50] Another paradox commonly found in the research was first highlighted by Lynell Johnson's major study in the USA. Dissonance was generally found between young people's optimistic personal futures and pessimistic national/global futures. [49] This finding was supported by research in the UK, Finland and Australia. [30, 48, 50, 54, 55] The dissonance is believed by many futurists to result from the continual bombardment of young people's imaginations by the media's presentation of negative, fearful collective futures. [56-58]

It should also be noted that we must caution against making naive deductions from the concepts of 'optimism' and 'pessimism'. [46, 53, 54] As Slaughter states: "It is true that pessimism may lead to despair. However, it may also stimulate a person to search for effective solutions. On the other hand, optimism may leave an individual's energy free for constructive projects or it may encourage bland, unhelpful, business-as-usual attitudes. In both cases the human response is crucial. Optimism and pessimism can both inhibit and encourage effective responses." [59]

\subsection{Differences by age}

Research with young people indicates that optimism about the future decreases with age. [60] Jane Page found that 4-5 year olds already possess many of the qualities that futurists try to impart. [61] David Hicks and Cathie Holden's major UK study show that whilst 7 year olds still have abundant optimism, this is increasingly replaced by a skeptical attitude. [7] The process also appears to continue - so that by 25 , apathy and disillusionment is widespread. [62]

\subsection{Differences by gender}

Hicks and Holden's UK research found that $40 \%$ of boys were attracted to a future dominated by technology compared to only $19 \%$ of girls. [7] Hutchinson also found that boys' images of the 'preferred future' fell largely into images of 'passive hope' where technology was the 'magical helper'; the girls were more able to envisage a 'greening of science'. [58]

Hicks and Holden also found that girls of all ages express more interest than boys in their own future, the futures of the community and the world. Secondary school girls feel that they can do something to make a difference whilst 18-year-old boys are the most cynical. [7] This finding runs somewhat counter to feminist arguments that maintain that girls are disadvantaged by the educational system. Supporting Hicks and Holden's point, recent research in Australia suggests that many boys are not thriving in the education system with only $61 \%$ currently completing secondary schooling. [63] Youth suicide statistics further indicate that young males are the most disempowered by hopelessness about current cultural conditions. [64]

\subsection{Differences by educational approach}

There has been little research on the impact of different educational approaches on youth's views of the future. Of significant note, however, has been a study of senior secondary students in the three largest Steiner schools in Australia. [23,65] These findings contrast markedly with research from mainstream schools:

- Steiner-educated students were able to develop richer, more detailed images of their 'preferred futures' than mainstream students. About three-quarters were able to envision positive changes in both the environment and human development; almost two-thirds were able to imagine positive changes in the socio-economic area.

- 'Social' - rather than 'technological' - futures emerged strongly as a way to solve problems.

- In envisioning futures without war, their visions primarily related to improvements in human relationships and communication through dialogue and conflict resolution rather than a 'passive peace' image. 
- $75 \%$ had many ideas on what aspects of human development (including their own) needed to be changed to enable the fulfilment of their aspirations. These included more activism, value changes, spirituality, future care and better education.

- In spite of identifying many of the same concerns as other students - global-scale environmental destruction, social injustice and threats of war, most of the Steiner students seemed undaunted in terms of their own will to do something to create their 'preferred future'.

- Interestingly, there were no gender differences found in the students' preferred futures visions or in the richness and fluidity of their creative images.

\subsection{Differences by culture}

The most comprehensive coverage of cross-cultural research can be found in the 2002 book, Youth Futures. [66] This book was originally inspired by the papers presented in the Youth Section of the WFSF Conference in Brisbane in 1997 following a series of conversations between WFSF members and the Queensland University of Technology Communication Centre. Included are perspectives from young people from Japan, Singapore, Pakistan and the Philippines. [67-70] In addition, Enric Bas' study of the future views of Spanish youth was published with a collection of papers presented at the WFSF Course in Budapest, Hungary in 1999. [71] In his overall research with non-Western youth futures, Inayatullah suggests that the non-West is mirroring the West. In Pakistan, however, the fatigue was not with development but with feudalism and state control, resulting in a desire to escape to high-income countries. Those who cannot escape have to make the 'best of it', which may mean high heroin addiction. [51] He also found that whilst the 'official discourse is religion, the unofficial is escape from religion and the chase for all things Western (T-Shirts, cigarettes, and rock music).' Ivana Milojevic's doctoral research also makes a vital contribution to the exploration of educational futures beyond the mainstream cultural discourse. Apart from broadening the concept of a single utopian versus dystopian duality, she embraces the movement towards heterotopias and eutopias, including dissenting futures such as the feminist, indigenous and spiritual. [72]

\section{Empowerment}

Research often ties together negativity towards the future with disempowerment. This need not be the case. As the above research with Steiner-educated students indicates, personal empowerment may also follow if the conditions are right. In this instance, the students' preparedness to act to solve the problems they envisioned suggests they were empowered by their style of education. [23] Other studies have additionally suggested that social and political activism can both lessen feelings of powerlessness in the face of global problems and also increase enthusiasm about personal future prospects. [55, 73] Empowerment-oriented futures techniques can also be valuable in countering young people's fears about the future [74-77] - as the following Australian research indicates.

A 2002 youth futures visioning project showed that after some initial difficulties, the youth were able to move from their local and somewhat cynical focus on 'lack of entertainment and shortage of places to hang around'. Their aspirations developed into thinking of their community as one where citizens could 'think, plan, dream and play'. After four workshops their final vision was one that portrayed in some detail 'a welcoming society, a sustaining environment, and an enterprising economy'. [78]

In the Re-Imagining Your Neighborhood project students were encouraged to imagine how a healthy neighborhood might look and feel. They then identified what was needed to create this neighborhood by talking with local government, conducting interviews, through community art, planting trees and designing public spaces. The findings indicate that the project was effective in helping students develop a greater sense of hope and possibility. [77]

Another pilot study made links between, on the one hand, the extensive psychological literature that has for decades linked hopelessness with depression and suicide-risk, and on the other hand, youth futures research which correlates rising youth suicide rates with young people's growing negativity towards the 
future. It explored the possibility that futures processes might quantifiably reduce levels of hopelessness in young people. [74] The program succeeded: their images of the future became significantly more positive after the intervention. There was also a marked improvement in the 'hopelessness' scores of the males. This has important implications given that suicide among young males is four times that of young women and also that adolescent boys are perceived as being a difficult group to influence. Some caution needs to be sounded, however: some of the girls actually became more hopeless. Also, some students who were already clinically depressed became more depressed initially, and needed individual debriefing sessions. Further work is clearly necessary.

Martha Rogers appears to have been the first researcher to investigate psychological processes in futures techniques. [79] She stressed that futures education is not just a cognitive process, but also moves the hearts and souls of those who enter into it. In her research, many students in the initial stages of learning about futures underwent considerable cognitive dissonance, confusion and discomfort. This led to the stirring of emotions that for some became a 'roller coaster' ranging from anger, depression, guilt and fear, to elation. These emotions were a part of a grief response to losing previously held worldviews, often followed by a new heart-felt caring for the world and others. There was then a soul awakening where the person's whole being became engaged in a search for new meaning. At each of these stages some self-help skills were needed to bring back balance in order to move on. Finally, she noted that finding a path to action was a crucial stage in bringing about a return to calm, personal power and renewed hope. [80]

\section{Pointers to preferable futures of 'futures in school education'}

Slaughter argues that in spite of its long history now spanning decades, futures in education is still marred by many obstacles not the least being that school systems are still 'quintessentially industrial era organizations' which are resistant to change.

His preferred approach is to develop 'foresight fostering' educational approaches - which would:

- introduce futures concepts and tools throughout the curriculum;

- integrate futures thinking into teacher training and professional development;

- relate curriculum frameworks to their wider, long-term context;

- use futures methods on strategic planning for schools and school systems; and

- revise the concept of educational leadership to include a proactive element. [28]

Regarding the curriculum, it is suggested here that those futures methodologies that include the facilitation of self-empowerment should be emphasised over those that do not pay due regard to psychological processes. In addition to empowerment methodologies already mentioned, two other frameworks may be noted which provide 'meta-methodologies' for practitioners to analyse and synthesise more complex issues.

The first is Inayatullah's Causal Layered Analysis. [16] This can be used for both diagnostic analysis and solution-based action, providing a way of moving beyond both empirical analysis and the relativism of post-structural analysis.

The second is Ken Wilber's integral framework. [81-83] This addresses the complexity of the present times where higher-order forms of thinking are called for - thinking that moves beyond narrow specialisations, reductionism, and small-minded 'rationality'. The integral framework incorporates multiples ways of knowing, being and acting in the world. Although its complexity can be critiqued as being too unwieldy to be useful, it promises to be a most rewarding approach, as its very raison d'etre is to embrace and appropriately place all paradigms through deeply respecting their unique perspectives. A comprehensive and balanced understanding can then be reached.

The application of integral thinking to the futures discipline is in its infancy, and is being pioneered, it seems, from Australia. [20] Slaughter's recent endeavours to broaden the futures knowledge base to include these new integral perspectives will ensure that WFSF will continue to be at the leading edge of the futures studies territory. [20,84] It is essential that futures studies as a field keeps up with (and indeed goes ahead of) the currents of 'new thinking' in the world. The integral movement with its various currents and 
facets carries within it the potential for the most transformative development in human consciousness since the European Enlightenment. Its implications for educational futures (and futures in education) therefore cannot be overlooked.

Although it is not possible in this article to draw out the full implications of the integral map, an initial scan of futures in school education using one aspect of this framework can nevertheless begin to indicate its usefulness. This aspect is the 'four quadrants' model.

\subsection{An introductory 'four quadrants' analysis}

Simply stated, four quadrants represent the inner and outer dimensions of the individual and the collective:

- $\quad$ upper left - UL - Subjective - Inner aspect of individual (intentional, psychological)

- $\quad$ upper right - UR - Objective - Outer aspect of individual (behavioural, physical)

- lower left - LL - Intersubjective - Inner aspect of collective (meaning systems, culture)

- lower right -- LR - Interobjective -- Outer aspect of collective (social systems and behaviour).

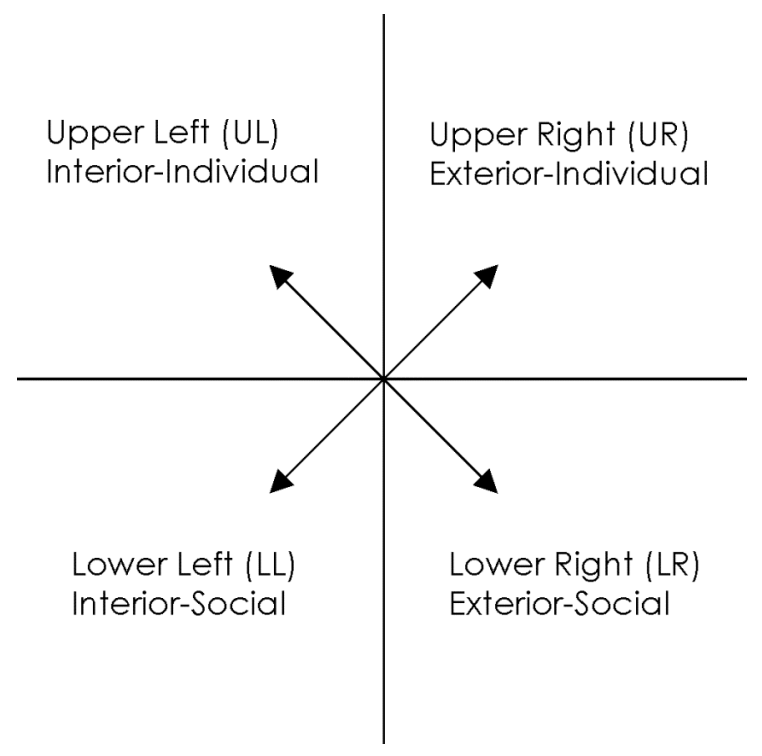

Figure 1 Wilber's Four Quadrants model

Although the quadrants are ontologically distinct, there is nevertheless an interwoven, intimate correspondence between them. Wilber argues that there needs to be a harmony between the quadrants if the whole system is to remain in balance: "An increase in exterior or social development can only be sustained with a corresponding increase in interior development of consciousness and culture". [20]

Taking 'futures in school education' as the focus, a number of points can be made.

- Most work has been within the two upper quadrants - introducing concepts and tools that increase an individual's knowledge base (UL) and perhaps their behaviour as well (UR). Although much of the work is done in classes and small groups, it is still primarily focussed on the development of the individual. Indeed, the problem of getting sufficient support from school systems to keep 
initiatives going may stem primarily from the lack of work to date within the cultural and social quadrants (LL and LR).

- Although much of the work in teaching futures is concerned with the upper left quadrant - the domain of the psychological, virtually no research has been conducted on the psychological processes involved in teaching futures. Yet the two are obviously intimately related. In this sense, even the best futures work has been largely unconscious of its own processes and has ignored the further development of this quadrant. Peter Hayward's current research is crucial in beginning to explore this terrain. $[85,86]$.

- Looking at the cultural quadrant (LL), we can see a lack of development of futures' cultural resources and artefacts. How many movies, songs, plays and art shows have arisen from the futures field? Although there are plenty of science fiction movies and books, most of these are dystopian. Rather than 'futures' as 'just another social science lesson', we need to enter youth culture through music and film -- and to inspire young people to help with this. The computer game model may be an ideal way of introducing futures concepts.

- Another area that requires more attention is social futures - looking at how people relate to each other (LL). Johan Galtung [87] has pointed out that when we hear the term 'future' we seem only to think of technological futures. However, there is much scope for development in this quadrant.

- The lower right quadrant should not be overlooked. Educational futurists have not significantly addressed 'the nature and dynamics of the relevant societal structure and systems [20]- in this case, the education system itself.

- In the LR we may also question the increasing use of technology - notably computers - in schools. Such is the prevalence of this issue, the term 'futuristic schools' is often limited to mean 'high-tech schools'. The increased usage of technology is not without its potential problems, however. A number of studies have begun to explore potential psychological and physical damage to children from long exposure to television screens and computer monitors. [88-92] Initial findings suggest a link, for example, between screen viewing and myopia ('short-sightedness').

\subsection{Other integral considerations}

In addition to this analysis, brief mention will be made here of other aspects of the integral approach. Firstly, the integral approach carries an injunction to 'practice' (as a complement to theory). [82] An example here would be the empowerment- oriented methodologies already mentioned. Secondly, a 'four quadrants' analysis should be seen as one part of a 'full spectrum' analysis, which would require us to also look at 'all types, all states, all streams, and all waves'. [82]

'Types' refers in this instance to different personality types. It may also be seen to refer to gender. 'States' of consciousness include waking, dreaming, sleeping, altered, and meditative.

'Streams' or 'lines' refer to the different aspects of our being such as the cognitive, ethical, empathic, creative, socio-emotional, communicative, spiritual, kinaesthetic, mathematical, sexual and musical. Taking the Upper Left Quadrant, the emphasis in school education and in futures in school education has been with developing cognition. 'Streams' support the latest developments in psychology that indicate there are multiple ways of knowing (artistic, contemplative, practical etc.) and that all are important for a balanced education. [93] In the Lower Left Quadrant, streams can represent different cultures and subcultures. This is an underrepresented area in futures work. For example, what do we educational futurists know about how young indigenous people frame the future? Apart from Milojevic's and Inayatullah's work and a few other studies, little futures in education work has been recorded in non-Western settings. [15, 16, $51,72,94]$

'Waves' refers to the different 'levels' of development occurring within an individual or society. For example, an important stream to consider in an analysis of the education process would be the different value-systems and worldviews that may be held by pupils, teachers and administrators. This particular developmental aspect may be investigated through the Spiral Dynamics model based on Clare Graves' 
pioneering work and developed by Don Beck and Christopher Cohen. [82] Although consideration of the waves of development is essential for a full integral analysis, space does not permit a due elaboration in this present article.

\subsection{Possible research areas}

As demonstrated in the integral analysis above, a number of gaps have been identified in the research and practice of futures in school education. Subsequently, a number of research focus areas and some specific questions have been formulated which, if undertaken, would greatly broaden and deepen the potential impact of this work. A sample of these is given below.

\section{Psychological dimensions}

i. Further general psychological research is needed into futures thinking/foresight.

ii. Why are Steiner students more empowered towards creating their preferred futures than mainstream youth and does this apply to students from non-Steiner alternative schools?

iii. Psychological implications of futures processes on clinical depression and hopelessness in young people need to be more fully explored.

iv. Further research is needed on the implications of the correlation between age and increasing pessimism.

v. Why are boys more passive and technologically oriented in their preferred futures images? And why are they more susceptible than girls to clinical levels of hopelessness? Can positive futures visioning help to reverse this?

\section{Diverse ways of knowing}

i. How can futures in education help to keep non-cognitive streams open?

ii. How could music be used as a futures tool?

iii. Is there a place for more poetry, dance and theatre in futures in school education?

iv. Is there a place for contemplative practices?

\section{Socio-cultural diversity}

i. What kind of research could inform futures in education processes so that they could be more inclusive of non-Western cultural values?

ii. How can futures in education foster the co-existence of a tapestry of different cultures on a global scale?

iii. How can we best explore alternatives to hegemonic conceptions of education? [72]

\section{Cultural resources}

i. There is a need for a resource bank to be developed of what cultural material (movies, literature, music, computer games) already exists which presents positive futures.

ii. Who will write the futures fiction of the future? Need it be 'science fiction'?

iii. How can young people be encouraged to write their own 'alternative futures fiction'?

iv. Is it possible to explore a popular form of expression of futures that appeals to student populations, for example through a competition?

\section{Human/social futures}

i. Why do technology futures figure so strongly in youth futures research?

ii. What images of future humans are the media presenting?

iii. How can our understanding of social innovation counteract 'over-technologised' futures?

iv. How can the stages of moral development of Kohlberg and Gilligan throw light on our framing of social futures? 
v. Why do Steiner students have such a strong emphasis on social futures?

vi. What might widen and deepen young people's capacity to imagine better social futures?

vii. What are the emerging issues relating to over-use of technology in education?

viii. How might the research at Sydney University on increasing biological myopia, linked to high screen usage in young people, also reflect a more socio-cultural or 'metaphoric myopia'?

\section{Tackling the social systems}

i. How are futures approaches currently being used in school systems and how could they be improved?

ii. Given that the 'future' is a current fashion in education, how can education systems be informed of the knowledge base of futures studies as a resource?

iii. Can the futures field provide strategies to better support teachers who wish to use innovative approaches?

iv. Who are the key power brokers in national curriculum initiatives? How can they be informed of futures studies resources?

v. How might futures best evaluate alternatives regarding educational administrative structures in education? How might futures in education benefit from school networking initiatives such as the OECD's Schooling for Tomorrow?

vi. School systems in some states contain futures in their frameworks. How can these be developed and applied more systematically?

vii. How has an increase in the use of computers in classrooms affected the teaching of futures?

viii. How can futures in education contribute to better communication and a re-evaluation of roles and expectations in teacher-teacher / teacher-pupil / pupil-pupil relationships? How might we regard the prevailing internal politics in schools?

\section{Developing integral consciousness}

i. How might a Spiral Dynamics analysis inform futures in school education?

ii. Could a futures curriculum, informed by developmental understandings, be developed for use from Pre-school to PhD?

iii. How can alternative approaches to education such as Steiner schooling or Aurobindo's integral education [95] inform futures in education?

iv. Is imagination one of the qualities necessary to develop an integral consciousness? If so, how can imagination be fostered by futures in education? What existing research is available on the cultivation of imagination in education?

v. What other existing organizations or networks are working towards an integral education approach with or without a futures perspective?

vi. Are there any existing cross-cultural visionary worldviews based in an integral paradigm?

vii. Does the capability of foresight arise from cultural evolution? Is a 'scientific' worldview antithetical to foresight? [86]

\section{Conclusion}

Regarding the development of foresight literacy: when you begin to take an integral view of futures in school education, it starts to become clearer why it has not had the impact or the staying power that futures researchers have expected. Because most work has been focused on a limited number of quadrants and a limited range of levels and streams within these, it will have limited overall impact on education and society no matter how good the work is. In this way, foresight literacy as a branch of education has barely started.

WFSF members have played a vital role in the research and development of futures in education. This review strongly suggests that these efforts should continue. It is hoped that WFSF, and especially the members of the WFSF Futures in Education Working Group, will consider this analysis and extend their research interests even further into some of these challenging and vital areas. 


\section{Notes and References}

1. Garrett, P., Toppling the House of Cards, in Looking Beyond Yesterday, D. Headon, Editor. 1990, Oxford University Press: Melbourne. p. 39-43

2. Ramos, J.M., From Critique to Cultural Recovery: Critical Futures Studies and Causal Layered Analysis. 2003, Australian Foresight Institute: Melbourne.

3. Slaughter, R., Towards a Critical Futurism, Part 1. World Future Society Bulletin, 1984: p. 19-25.

4. Slaughter, R., Towards a Critical Futurism. Part two: Revising and Refining a Futurist Perspective. World Future Society Bulletin, 1984: p. 11-16.

5. Slaughter, R., Towards a Critical Futurism. Part three: An Outline of Critical Futurism. World Future Society Bulletin, 1984(Sept/Oct): p. 17-21.

6. Inayatullah, S., Deconstructing and reconstructing the future: Predictive, cultural and critical epistemologies. Futures, 1990. 22(2): p. 115-141.

7. Hicks, D. and C. Holden, Visions of the Future: Why we Need to Teach for Tomorrow. 1995, London: Trentham Books.

8. Hicks, D., Preparing for the Future: Notes and Queries for Concerned Educators. 1994, London: Adamantine Press.

9. Hicks, D., Lessons for the Future. Futures and Education Series, ed. R. Slaughter. 2002, London: Routledge.

10. Slaughter, R., Towards an Agenda for Institutions of Foresight. Futures, 1995. 27(1): p. 91-95.

11. Slaughter, R., What is Futures Education?, in Studying the Future: an Introductory Reader, R. Slaughter, Editor. 1989, Commission for the future, Bicentennial futures education project: Melbourne. p. 10-20.

12. Slaughter, R., ed. Studying the Future: An Introductory Reader. 1989, Commission for the future, Bicentennial futures education project: Melbourne.

13. Slaughter, R., What Can We Know About the Next 20 Years? 1994, Australian Catholic University, School of Education, Victoria.

14. Inayatullah, S., Frames of Reference, the Breakdown of the Self, and the Search for Reintegration: Some Perspectives on the Futures on Asian Cultures, in The Futures of Asian Cultures, E.a.A. Masini, Y, Editor. 1993, UNESCO: Bangkok. p. 95-131: Ch7.

15. Inayatullah, S., Futures Visions for South-east Asia: some early warning signals. Futures, 1995. 27(6): p. 681688.

16. Inayatullah, S., Alternative Futures: Methodology, Society, Macrohistory and the Long-Term Future, in Tamkang Chair Lecture Series. 2000: Taipai.

17. Sardar, Z., Conquests, Chaos and Complexity: The Other in Modern and Postmodern Science. Futures, 1994. 26(6): p. 665-682.

18. Wildman, P., Futures Studies: Methods, Issues and Visions, S. Inayatullah, Editor. 1995: Southern Cross University.

19. Inayatullah, S., ed. The Causal Layered Analysis (ClA) Reader Epistemology and Methodology in Praxis. forthcoming.

20. Slaughter, R., Integral Futures - a New Model for Futures Enquiry and Practice. 2003, Australian Foresight Institute: Melbourne.

21. Bjerstedt, A., Future Consciousness and the School. Educational Information Debate, ed. A. Bjerstedt. Vol. 62. 1982, Malmo: School of Education, University of Lund, Sweden. 93.

22. Boulding, E., Image and Action in Peace Building. Journal of Social Issues, 1988. 44(2): p. 17-37.

23. Gidley, J., Prospective Youth Visions through Imaginative Education. Futures, 1998. 30(5): p. 395-408.

24. Hutchinson, F., Futures consciousness and the school: Explorations of broad and narrow literacies for the twenty-first century with particular reference to Australian young people. 1992, University of New England: Armidale NSW. p. 410.

25. Wildman, P. and S. Inayatullah, Ways of Knowing, Culture, Communication and the Pedagogies of the Future. Futures, 1996. 28(8): p. 723-740.

26. Gidley, J., The Metaphors of Globalisation: A multi-layered analysis of global youth culture, in The Causal Layered Analysis (CLA) Reader

Epistemology and Methodology in Praxis, S. Inayatullah, Editor. forthcoming.

27. Voros, J., Integral Futures - a Brief Outline. 2003, Australian Foresight Institute. 
28. Slaughter, R., From Rhetoric to Reality: the Emergence of Futures into the Educational Mainstream, in Youth Futures: Comparative Research and Transformative Visions, J. Gidley and S. Inayatullah, Editors. 2002, Praeger: Westport. p. 175-186.

29. Jackson, C., Learning with an Active Voice, in Youth Futures: Comparative Research and Transformative Visions, J. Gidley and S. Inayatullah, Editors. 2002, Praeger: Westport, CT.

30. Hicks, D., Envisioning the future: The challenge for environmental educators. Environmental Education Research, 1995. 1(3): p. 1-9.

31. Hicks, D., Educating for the Future: A Practical Classroom Guide. 1994, UK: Godalming, World Wide Fund for Nature.

32. Hicks, D., A Lesson for the Future. Futures, 1996. 28(1): p. 1-13.

33. Hicks, D., Identifying Sources of Hope in Post-modern Times, in World Yearbook of Education 1998: Futures Education, D. Hicks and R. Slaughter, Editors. 1998, Kogan Page: London.

34. Hicks, D., Citizenship for the Future: A Practical Classroom Guide. 2001, Surrey: World Wildlife Fund-UK.

35. Hicks, D., Re-examining the future: the challenge for citizenship education. Educational Review, 2001. 53(3): p. 57-60.

36. Holden, C., Citizens of the New Century: Perspectives from the United Kingdom, in Youth Futures: Comparative Research and Transformative Visions, J. Gidley and S. Inayatullah, Editors. 2002, Praeger: Westport, CT. p. 131-142.

37. Sterling, S., Sustainable Education, in Schumacher Briefings. 2001: Bristol.

38. Fien, J., Environmental Education for a New Century, in World Yearbook 1998: Futures Education, D. Hicks and R. Slaughter, Editors. 1998, Kogan Page: London.

39. Orr, D., The Nature of Design. 2001, Oxford: Oxford University Press.

40. Hutchinson, F., Making peace with people and planet: some important lessons from the Gandhian tradition in educating for the 21st Century. Peace, Environment and Education, 1992. 3(3): p. 3-14.

41. Fien, J., Teaching and Learning for a Sustainable Future. 2002, UNESCO.

42. Smith, C. Futures Studies in the Secondary and Tertiary Sectors: An Overview. in Futures in Education Forum. 2003. Australian Foresight Institute.

43. Gough, N., Futures in Australian Education: Tacit, Token and Taken for Granted Futures. Futures, 1990. April: p. 298-310.

44. Eckersley, R., Casualties of change: The predicament of youth in Australia. An analysis of the social and psychological pressures faced by young people in Australia. 1988, Australia's Commission for the Future: Melbourne.

45. Eckersley, R., Youth and the challenge to change. Bringing youth and society together in the new millennium. Apocalypse No! Series. 1992, Australia's Commission for the Future: Melbourne.

46. Eckersley, R., Values and visions: Youth and the failure of modern Western culture. Youth Studies Australia, 1995. 14(1): p. 13-21.

47. Hannan, B., et al., Charting a Course: Students' Views of their Future. 1995, Schools Council, National Board of Employment, Education and Training: Canberra.

48. Wilson, N., The state of the planet and young people's minds, in Studying the Future: An Introductory Reader, R. Slaughter, Editor. 1989, Commission for the Future, Bicentennial Futures Education Project: Melbourne. p. 36-41.

49. Johnson, L., Children's visions of the future. The Futurist, 1987: p. 36-40.

50. Eckersley, R., Having our Say about the Future: Young People's Dreams and Expectations for Australia in 2010 and the Role of Science and Technology. 1996, Australian Science and Technology Council.

51. Inayatullah, S., Youth Dissent: Multiple Perspectives on Youth Futures, in Youth Futures: Comparative Research and Transformative Visions, J. Gidley and S. Inayatullah, Editors. 2002, Praeger: Westport, Connecticut.

52. Gough, N. Alternative futures in environmental education. in 3rd national environmental education seminars and workshops, Environmental education - past, present and future. 1987. Canberra: AGPS. p37

53. Hutchinson, F., Educating beyond Fatalism and Impoverished Social Imagination: are we actively listening to young people's voice on the future? 1994: School of education, Malmo, Sweden. 24-45.

54. McGregor, P., Visions of the future, in Studying the Future: The Introductory Reader, R. Slaughter, Editor. 1989, Commission for the Future, Bicentennial Futures Education Project: Melbourne. p. 30-35.

55. Rubin, A. Unfolding Tomorrow: Adolescents' Images of the Future as the Strategies for Coping with Transition. in Cultural Alienation. 1996. Losarvi, Finland: unpublished.

56. Eckersley, R., The West's deepening cultural crisis. The Futurist, 1993: p. 8-20. 
57. Gidley, J., Cultural Renewal: Revitalising Youth Futures, in New Renaissance. 2000. p. 14-16.

58. Hutchinson, F., Educating Beyond Violent Futures, ed. R. Slaughter. 1996, London: Routledge. 304.

59. Slaughter, R., Futures Tools and Techniques. 1995, Melbourne: Futures Studies Centre.

60. ACER, Schools and the Social Development of Young Australians. Youth Studies Australia, 1998. p.93

61. Page, J., Reframing the Early Childhood Curriculum: Educational Imperatives for the Future. 2000, London: Routledge.

62. ACF, Youth Futures Program. 1996, Australian Commission for The Future. p. 14.

63. Gidley, J., Young People's Values and Aspirations in Australia in 2002/3. 2003, ECEF (Enterprise Careers Education Foundation): Sydney.

64. Eckersley, R., Future visions, Social Realities and Private Lives: Young People and their Personal Well-being, in Youth Futures: Comparative Research and Transformative Visions, J. Gidley and S. Inayatullah, Editors. 2002, Praeger: Westport, CT. p. 31-42.

65. Gidley, J., Holistic Education and Visions of Rehumanized Futures, in Youth Futures: Comparative Research and Transformative Visions, J. Gidley and S. Inayatullah, Editors. 2002, Praeger: Westport, Connecticut.

66. Gidley, J. and S. Inayatullah, Youth Futures: Comparative Research and Transformative Visions. 2002, Westport, Connecticut: Praeger.

67. Aslam, B., Voice of the Future from Pakistan, in Youth Futures: Comparative Research and Transformative Visions, J. Gidley and S. Inayatullah, Editors. 2002, Praeger: Westport, CT.

68. Guanco, M., Shared Futures from the Philippines, in Youth Futures: Comparative Research and Transformative Visions, J. Gidley and S. Inayatullah, Editors. 2002, Praeger: Westport, CT.

69. Oehlers, A., Imagining the Future: Youth in Singapore, in Youth Futures: Comparative Research and Transformative Visions, J. Gidley and S. Inayatullah, Editors. 2002, Praeger: Westport, CT.

70. Wright, D., Japanese Youth: Rewriting Futures in the "No Taboos" Postbubble Millennium, in Youth Futures: Comparative Research and Transformative Visions, J. Gidley and S. Inayatullah, Editors. 2002, Praeger: Westport, CT.

71. Novaky, E., The Youth for a Less Selfish Future: Papers of the Budapest Futures Course. 2000, Budapest: Budapest University.

72. Milojevic, I., Futures of Education: Feminist and Post-Western Critiques and Visions. PhD Thesis, in Education. 2002, University of Queensland: Brisbane.

73. Kleiber, D., W. Major, and G. Manaster, Youths' Outlook on the Future IV: A Third Past-Present Comparison. Youth and Society, 1993. 24(4): p. 349-362.

74. Gidley, J., An Intervention Targeting Hopelessness in Adolescents by Promoting Positive Future Images. Australian Journal of Guidance and Counselling, 2001. 11(1): p. 51-64.

75. Hart, S., Rural Visions of the Future: Futures in a Social Science Class, in Youth Futures: Comparative Research and Transformative Visions, J. Gidley and S. Inayatullah, Editors. 2002, Praeger: Westport, Connecticut.

76. Head, S., I Don't Care about the Future (if I Can't Influence it), in Youth Futures: Comparative Research and Transformative Visions, J. Gidley and S. Inayatullah, Editors. 2002, Praeger: Westport, Connecticut.

77. Stewart, C., Re-Imagining your Neighbourhood: A Model of Futures Education, in Youth Futures: Comparative Research and Transformative Visions, J. Gidley and S. Inayatullah, Editors. 2002, Praeger: Westport, CT. p. 187-196.

78. Lee Martin, J., Jigsaw Project. 2002, Futures Foundation: Wyong.

79. Rogers, M. and A. Tough, What happens when students face the Future. Futures Research Quarterly, 1992. Winter: p. 9-18.

80. Rogers, M., Student Responses to Learning about the Future, in World Yearbook of Education 1998: Futures Education, D. Hicks and R. Slaughter, Editors. 1998, Kogan Page: London.

81. Wilber, K., Integral Psychology: Consciousness, Spirit, Psychology, Therapy. 2000, Boston: Shambhala. 302.

82. Wilber, K., A Theory of Everything. 2000, Boulder: Shambhala.

83. Wilber, K., Sex, Ecology, Spirituality: The Spirit of Evolution. 1995, Boston and London: Shambhala.

84. Gebser, J., The Ever-Present Origin. 1991, Athens, Ohio: Ohio University Press.

85. Hayward, P., Resolving the Moral Impediments to Foresight Action. Foresight, 2002. 5(1): p. 4-10.

86. Hayward, P., Foresight in Everyday Life, in AFI Monograph Series. 2003: Melbourne. p. 42.

87. Galtung, J., Schooling, Education and the Future. Educational information and debate. Vol. 61. 1982, Malmo, Sweden: Department of Education and Psychology Research, Lund University. 91.

88. Benoit, M., The Dot.Com Kids and the Demise of Frustration Tolerance, in The Future of Childhood, C. Clouder, S. Jenkinson, and M. Large, Editors. 2000, Hawthorn Press: Gloucestershire. 
89. Grossman, D., Teaching Kids to Kill, in The Future of Childhood, C. Clouder, S. Jenkinson, and M. Large, Editors. 2000, Hawthorn Press: Gloucestershire.

90. Grossman, D., G. Degaetano, and D. Grossman, Stop Teaching our Kids to Kill: a Call to Action against TV, Movie and Video Violence. 1999, NY: Random House.

91. Healey, J., Failure to Connect: How computers affect our children's minds - and what we can do about it. 1998, New York: Touchstone.

92. Large, M., Out of the Box, in The Future of Childhood, C. Clouder, S. Jenkinson, and M. Large, Editors. 2000, Hawthorn Press: Gloucestershire.

93. Gardner, H., Probing more Deeply into the Theory of Multiple Intelligences. NASSP Bulletin, 1996. 80(583): p. 1-7.

94. Milojevic, I., Hegemonic and marginalised educational utopias in the contemporary western world. Policy Futures in Education, 2003. 1(3).

95. Aurobindo Ghose, S., The Graded Worlds, in The Riddle of This World, S. Aurobindo Ghose, Editor. 1930, Sri Aurobindo Ashram: Pondicherry, India. 